\title{
DILEMA PENGAWASAN PARTISIPATIF: IKATAN PATRIMONIAL DAN MASYARAKAT YANG TERKOOPTASI DI JAWA TIMUR
}

\author{
Andy IIman Hakim \\ Program Studi Ilmu Politik FISIP Universitas Brawijaya Malang \\ andyilmanhakim@ub.ac.id \\ Deydeandy L. Iztighfari \\ Program Pascasarjana IImu Politik FISIP Universitas Indonesia \\ deydeandy@gmail.com
}

\begin{abstract}
The concept of participatory oversight focuses on people's involvement in election monitoring. This means that the people are not only built on awareness to exercise their right to vote, but also to be actively involved in the entire election process. The implementation of participatory oversight has been running and implemented since the 2009 elections. However, there are still various problems, especially in East Java Province. The number of people in East Java who use voting rights is very high, but the data shows that East Java is the province with the highest of election violations and people's involvement in reporting violations is very weak. This research uses a qualitative approach to analyze the problem of people's involvement in election monitoring. The research findings show the three important aspects that cause low people's involvement in the election monitoring process in East Java. First, there is no work innovation from Bawaslu at regional level. Second, patrimonial society. Third, found the practice of money politics and intimidation to the people by the political elite hurts society. The negative impact creates the problem of election monitoring by the public in East Java, as an impact of co-opted communities.
\end{abstract}

Keywords: monitoring, participatory, people,election 


\begin{abstract}
Abstrak
Konsep pengawasan partisipatif menitikberatkan pada keterlibatan masyarakat di dalam fungsi pengawasan Pemilu. Artinya, masyarakat tidak saja dibangun kesadarannya untuk menggunakan hak pilih, namun juga turun tangan terlibat aktif di dalam mengawasi proses Pemilu. Implementasi konsep pengawasan partisipatif sebenarnya sudah berjalan dan diterapkan sejak Pemilu 2009. Namun, dalam penyelenggaraannya di Pemilu Serentak tahun 2019 masih mengalami berbagai permasalahan, terutama di Provinsi Jawa Timur. Tingkat partisipasi memilih masyarakat Jawa Timur yang hadir menggunakan hak suara terbilang sangat tinggi. Ironinya, pada Pemilu Serentak 2019 data Bawaslu menunjukkan bahwa Jawa Timur menjadi provinsi tertinggi dalam aspek temuan pelanggaran namun rendah dalam aspek laporan pelanggaran dari masyarakat kepada Bawaslu di tingkat daerah. Ini menandakan bahwa keterlibatan masyarakat di dalam proses pengawasan Pemilu masih sangat lemah. Menggunakan pendekatan kualitatif, penelitian ini hadir untuk menganalisis persoalan yang muncul dalam konteks implementasi pengawasan partisipatif di wilayah Jawa Timur. Temuan penelitian menunjukkan bahwa ada tiga aspek penting yang menyebabkan rendahnya tingkat keterlibatan masyarakat dalam proses pelaksanaan pengawasan partisipatif di tingkat daerah. Pertama, berkaitan dengan persoalan kinerja Bawaslu di tingkat daerah dalam aspek inovasi pengawasan. Kedua, berkaitan dengan kondisi sosio kultur masyarakat Jawa Timur yang patrimonial. Ketiga berkaitan dengan praktik politik uang dan praktik intimidasi kepada masyarakat oleh kontestan pemilu. Hasil penelitian menyimpulkan bahwa rendahnya partisipasi politik masyarakat dalam aspek pengawasan di Jawa Timur banyak dipengaruhi oleh kondisi sosio-kultur dan masyarakat yang terkooptasi.
\end{abstract}

Kata Kunci : pengawasan, partisipatif, masyarakat, pemilu 


\section{Pendahuluan}

Beberapa negara dunia ketiga telah mengalami fase perkembangan masyarakat sipil sebagai dampak dari penerapan demokrasi prosedural. Prosedur utama demokrasi adalah pemilihan para pemimpin secara kompetitif oleh rakyat yang mereka pimpin (Huntington, 1991). Proses sirkulasi elit yang semula sama sekali tidak melibatkan partisipasi rakyat akibat praktik tata kelola pemerintahan otoriter, kini menuntut terlibatnya rakyat secara luas di setiap proses-proses politik negara. Sementara kesadaran masyarakat sangat terbatas mengenai aturan main di dalam proses politik, terutama di negara berkembang yang tengah berupaya menciptakan konsolidasi demokrasi. Beberapa persoalan mendasar kemudian muncul di setiap perhelatan politik, pemilu misalnya. Kontestasi yang melibatkan seluruh warga negara, seketika menuntut masyarakat untuk bertransformasi menggugah kesadaran politiknya mengatasi berbagai ketimpangan sosial, politik, maupun ekonomi.

Persoalan mendasar namun vital, yang melingkupi negara-negara berkembang dalam upaya menuju penerapan demokrasi secara substantif terletak pada aspek individu. Bay (dalam Varma, 1999) dalam menempatkan kemerdekaan individual manusia sebagai tujuan politik yang mendasar. Menurutnya, penegakan demokrasi yang benar haruslah di dahului dengan suatu rekonstruksi sosial yang radikal yang akan memungkinkan pencapaian kepuasan yang sesungguhnya dan martabat yang tinggi sebagai warga negara yang demokratis (Bay, 1958). Negara tidak saja membuka akses politik seluasluasnya untuk rakyat, namun juga turut andil mempermudah penciptaan iklim psikologis yang mampu membangkitkan pengembangan diri rakyat itu sendiri. Partisipasi aktif pada gilirannya menjadi kesempatan masyarakat mengembangkan kemampuan, yang pada akhirnya mengarah pada kesejahteraan dan kebaikan masyarakat dalam komunitas politik.

Secara ideal, partisipasi masyarakat secara luas di setiap tingkatan proses pemilu (full participation) merupakan indikator penting mewujudkan pemilu demokratis. Proses kompetisi elit dalam perebutan kekuasaan pada konteks ini menempatkan rakyat sebagai pemilik kedaulatan tertinggi. Evaluasi terhadap kinerja elit, ketidakpuasan rakyat, bahkan intervensi rakyat secara langsung terhadap proses kompetisi tersebut dapat dilakukan secara absah melalui proses pemilu. Penekanan partisipasi politik tidak saja terbatas pada tingkat kehadiran masyarakat pemilih di dalam bilik suara (turn out voter). Sementara ruang yang diberikan negara membuka peluang masyarakat untuk mengawasi seluruh tingkatan di dalam proses pemilu. Partisipasi aktif masyarakat memungkinkan tidak adanya warga negara yang terpinggirkan, mempersempit praktik manipulasi suara, bahkan praktikpraktik kompetisi yang tidak sehat. Sehingga penting bagi masyarakat untuk terlibat penuh di dalam proses-proses politik baik melalui pemilihan maupun pengangkatan.

Fenomena yang terjadi pada Pemilu Serentak tahun 2019 di Indonesia justru mengalami anomali partisipasi masyarakat. Berdasarkan hasil jurnalistik 
kompas, KPU menyebutkan angka partisipasi pada pemilu 2019 mengalami peningkatan dari pemilu sebelumnya. Jika pada Pemilu 2014 partisipasi berada pada angka $70 \%$ untuk pilpres dan $75 \%$ untuk pileg, pada Pemilu Serentak 2019 angka partisipasi meningkat hampir $10 \%$ menjadi 81\% (Farisa, 2019). Sementara Bawaslu RI (2019) telah merilis data pelanggaran nasional berkaitan dengan Laporan Dugaan Pelanggaran dan Temuan Dugaan Pelanggaran. Dari total 7.598 laporan/temuan dugaan pelanggaran, jenis pelanggaran yang telah diproses Bawaslu meliputi 458 pelanggaran pidana, 149 pelanggaran kode etik, 5.319 pelanggaran administrasi, 134 pelanggaran masih dalam proses, 730 pelanggaran hukum lainnya, serta 798 kategori bukan pelanggaran.

Tabel 1.1. Data Pelanggaran Pemilu Tahun 2019

\begin{tabular}{c|c|c|}
$\begin{array}{c}\text { Penerimaan } \\
\text { Laporan }\end{array}$ & $\begin{array}{c}\text { Penerimaan } \\
\text { Temuan }\end{array}$ & $\begin{array}{c}\text { Laporan/ } \\
\text { Temuan yang } \\
\text { Diregistrasi }\end{array}$ \\
\hline $\begin{array}{c}1.329 \\
\text { Laporan }\end{array}$ & $\begin{array}{c}7.183 \\
\text { Temuan }\end{array}$ & $\begin{array}{c}\text { 7.598 Temuan/ } \\
\text { Laporan }\end{array}$ \\
\hline
\end{tabular}

Sumber: Bawaslu RI, 2019.

Data diatas mengkonfirmasi di samping tingginya angka partisipasi masyarakat, juga ditemukan tingginya angka pelanggaran pada proses penyelenggaran Pemilu. Lebih spesifik, data memberikan gambaran perbandingan tingkat laporan masyarakat dan temuan Bawaslu terhadap dugaan pelanggaran sangat timpang. Artinya tidak banyak masyarakat terlibat aktif di dalam mengawal proses-proses Pemilu. Dari seluruh provinsi di Indonesia, Jawa Timur adalah provinsi dengan tingkat pelanggaran tertinggi dalam pelaksanaan Pemilu 2019, yaitu sebesar 3.002 temuan (Bawaslu RI, 2019). Sangat ironis saat angka temuan pelanggaran tinggi sementara data laporan dugaan pelanggaran dari masyarakat kepada Bawaslu sangat rendah. Sementara Ketua KPU Jawa Timur menyebut angka partisipasi masyarakat Jawa Timur pada Pemilu 2019 meningkat pesat mencapai 82,35\% (Amaluddin, 2019). Rumusan masalah ini membuka ruang untuk menganalisis masalah-masalah partisipasi masyarakat yang berkaitan dengan implementasi pengawasan partisipatif yang sudah berjalan pada Pemilu Serentak 2019 di Jawa Timur.

\section{Jumlah Pelanggaran Tertinggi'}

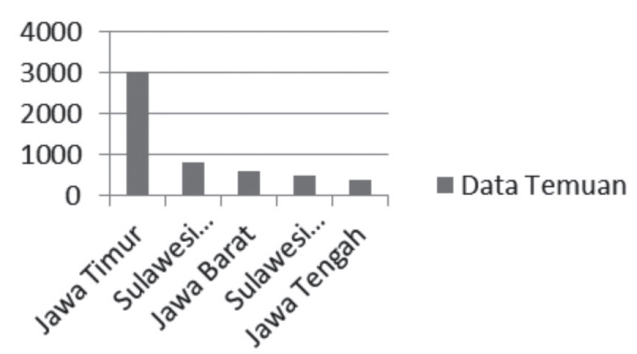

Gambar 1. Data Temuan Tertinggi Sumber: Bawaslu RI, 2019

\section{Metode Penelitian}

Penelitian ini menggunakan metode penelitian kualitatif yang bersifat deskriptif analisis dengan menggunakan paradigma interpretatif. Dengan sudut pandang interpretatif peneliti ingin memahami dan memaknai secara mendalam tentang fenomena yang terjadi di lingkungan sosial dalam bentuk deskripsi dan penjelasan mengenai fenomena yang akan dikaji. Selanjutnya, Creswell (2008, hlm. 15) menjelaskan bahwa metode kualitatif adalah suatu 
proses penelitian dan pemahaman berdasarkan pada metodologi yang menyelidiki suatu fenomena sosial dan masalah manusia. Pendekatan kualitatif dipilih dalam penelitian ini karena mampu mengeksplorasi secara mendalam dan detail terhadap sebuah fenomena tertentu, khususnya penjelasan mengenai evaluasi pengawasan partisipatif sebagai fungsi pengawasan Pemilu 2019 di Provinsi Jawa Timur.

Sumber data dalam penelitian ini diperoleh melalui wawancara mendalam (depth interview) dan studi kepustakaan. Data primer yang digunakan merupakan hasil penjelasan Informan penelitian dari kegiatan wawancara mendalam, antara lain hasil wawancara bersama Komisioner Bawaslu di beberapa kota/ kabupaten di Jawa Timur, praktisi/ akademisi yang concern di bidang politik dan pemilu khususnya di Jawa Timur, serta tenaga ahli DPR RI dan tim sukses salah satu pasangan calon di dapil XI Jawa Timur. Studi kepustakaan juga diperlukan sebagai data sekunder, berasal dari dokumen-dokumen seperti data laporan pelanggaran Pemilu 2019 yang dirilis oleh Bawaslu RI, karya jurnalistik beberapa media massa, serta studi literatur seperti jurnal maupun hasil penelitian terdahulu.

\section{Perspektif Teori}

Penelitian ini menggunakan beberapa pendekatan untuk membantu menganalisis faktor-faktor yang menyebabkan rendahnya keterlibatan masyarakat dalam aspek kontrol yaitu pengawasan proses-proses pemilu. Pertama, teori partisipasi politik membantu menganalisis urgensi pengawasan partisipatif. Serta teori elit di dalam iklim demokrasi untuk menganalisis posisi, peran, dan motivasi elit di dalam proses kompetisi. Konsep dasar keberadaan kelas elit dalam tatanan kehidupan masyarakat bersandar pada kenyataan adanya pembagian kategori secara luas yang mencakup sekelompok kecil manusia yang menduduki posisi untuk memerintah dan sejumlah besar massa yang diperintah. Lebih spesifik, komposisi di dalam kelompok penguasa selain elit yang berkuasa itu sendiri, juga ada elit tandingan. Atau dalam bahasa Pareto, elit tandingan dimaknai sebagai lapisan atas di dalam kelas masyarakat yang disebut dengan istilah non-governing elite atau elit yang tidak memerintah. Keberadaan komposisi ini mengarahkan fokus pada pendekatan pergantian elit yang memungkinkan kompetisi antar elit dan dampaknya pada masyarakat yang lebih besar (Varma, 1999, hlm.200).

Menurut Mosca, sebagaimana dikutip oleh Varma (1999, hlm.204) dalam suatu masyarakat politik yang besar, semakin kecil proporsi yang memerintah untuk diatur maka semakin sulit bagi masyarakat untuk mengorganisir reaksi mereka terhadap kelompok elit tersebut. Penguasaan minoritas atas mayoritas dilakukan dengan cara yang terorganisasi, yang menempatkan mayoritas tetap berdiri saja di belakang, apalagi kelompok minoritas biasanya terdiri dari individuindividu yang superior. Individu superior tersebut mencoba menemukan basis moral dan hukum bagi keberadaannya dalam benteng kekuasaan serta mewakilinya sebagai konsekuensi yang perlu dan logis atas doktrin-doktrin dan kepercayaan-kepercayaan yang secara umum telah dikenal dan diterima, yang kemudian dengan cerdik diatur untuk menipu massa.

Andy IIman Hakim \& Deydeandy L. Iztighfar 
Suatu perubahan dari bentuk demokrasi yang ada saat ini kepada demokrasi partisipasi akan memerlukan: (1) perubahan kesadaran rakyat, yang tadinya memandang diri mereka sebagai penerima pasif atas segala sesuatu yang diberikan oleh kekuasaan menjadi agenagen perubahan sosial yang aktif melalui bentuk partisipasi yang positif dalam proses pengambilan keputusan oleh negara; (2) pengurangan secara besarbesaran segala ketimpangan yang ada (Varma, 1999, hlm.222-223). Partisipasi politik tidak saja menjadi salah satu aspek penting dalam sebuah tatanan negara demokrasi, namun juga menekankan adanya keterlibatan masyarakat dalam segala proses tahapan kebijakan, mulai dari pembuatan keputusan, penilaian keputusan, hingga peluang untuk ikut serta dalam pelaksanaan keputusan (Huntington dan Nelson, 1994). Lebih lanjut, Weiner (1971, hlm. 164) menjelaskan bahwa partisipasi politik mengacu pada tindakan sukarela, berhasil atau tidak berhasil, terorganisir atau tidak terorganisir, berepisode atau berkelanjutan, menggunakan metode yang sah atau tidak sah, yang dimaksudkan untuk memengaruhi pilihan kebijakan publik, administrasi urusan publik, atau pilihan pemimpin politik di setiap tingkat pemerintahan, lokal atau nasional. Dapat dikatakan keterlibatan masyarakat di seluruh proses politik dimaksudkan untuk memperkuat tatanan demokrasi.

Bentuk partisipasi dalam kegiatan politik diklasifikasikan ke dalam dua konteks yaitu konvesional dan nonkonvensional (Almond, dalam Mas'oed dan MacAndrews, 2008). Misalnya secara normal berbentuk pemberian hak suara, diskusi politik, kampanye, membentuk dan bergabung dalam kelompok kepentingan, serta melakukan komunikasi individual dengan pejabat politik. Selain itu juga dalam bentuk partisipasi politik yang tidak lazim dilakukan dalam kondisi normal, bahkan dapat berupa kegiatan ilegal, penuh kekerasan dan revolusioner. Misalnya pengajuan petisi, demonstrasi, konfrontasi, mogok kerja, tindakan kekerasan politik terhadap harta benda hingga tindakan kekerasan politik terhadap manusia.

Dalam konteks pemilu, mengacu pada standar internasional tentang pemilu demokratis yang dipublikasilan oleh Organization for Security and Coperation in Europe/ OSCE (2010), mengungkapkan bahwa salah satu prinsip yang harus dirujuk dan dijadikan komitmen bersama antara pemerintah, penyelenggara pemilu, partai politik peserta pemilu, kandidat politik, pemantau pengawas pemilu dan masyarakat luas (warga negara) adalah terciptanya pemilu yang bebas (free elections). Prinsip free elections dalam hal ini merangkum bentuk-bentuk partisipasi politik dalam pemilu yang tidak terbatas pada hal-hal yang berkaitan dengan keterlibatan menjadi peserta pemilu dan pemberian hak suara semata, melainkan juga memastikan berjalannya fungsi pengawasan atas setiap tahapan pemilu.

Pengawasan pemilu yang efektif dipercaya sebagai instrumen yang mampu menghadirkan jaminan atas pelaksanaan pemilu yang demokratis. Surbakti \& Fitrianto (2015) menjelaskan absennya jaminan bahwa setiap pemilu pastilah demokratis, mendorong kebutuhan sebuah instrumen yang mampu memberikan jaminan legitimasi demokratis dari pelaksanaan pemilu tersebut. Instrumen tersebut harus 
mampu menjamin dan mempromosikan transparansi, akuntabilitas, kredibilitas dan integritas dari pelaksanaan pemilu. Jaminan ini menjadi penting karena berimplikasi pada kepercayaan publik terhadap proses pemilu, hasil pemilu dan juga kepada demokrasi itu sendiri.

\section{Hasil dan Pembahasan}

\subsection{Sejumlah Masalah Klasik}

Sejumlah catatan yang menunjukkan upaya Bawaslu RI menciptakan sistem pengawasan partisipatif dilakukan dengan menciptakan instrumen pengawasan yang berjudul Panduan Pengawasan Partisipatif. Instrumen tersebut memuat beberapa program besar misalnya Gowaslu, Forum Warga Pengawas Pemilu, GEMPAR, Pengabdiaan Masyarakat dalam Pengawasan Pemilu, Panduan Pengelolaan Media Sosial, Pojok Pengawasan Pemilu dan Saka Adhyasta Pemilu atau Gerakan Pramuka Daerah (Bawaslu RI, 2017). Secara substantif, arah program diatas mendorong keterlibatan masyarakat seluas mungkin untuk turut mengawasi penyelenggaraan Pemilu, terutama Pemilu Serentak 2019. Meskipun yang terimplementasi di wilayah kota/ kabupaten di Jawa Timur tidak demikian. Implementasi pengawasan partisipatif di daerah, terbatas pada sosialisasi dan FGD yang cenderung tidak terukur sasaran dan output programnya, minim inovasi, serta cenderung tidak berdampak signifikan (FW dan AF, Wawancara 2019). Terbukti, dari 3.002 temuan dugaan pelanggaran di Jawa Timur, hanya 55 laporan masyarakat yang diterima Bawaslu tingkat kota/ kabupaten (Bawaslu Jatim, 2019). Ketimpangan tersebut mengkonfirmasi adanya sejumlah persoalan di dalam kinerja Bawaslu tingkat kota/kabupaten.
Beberapa temuan yang menjadi alasan klasik misalnya rendahnya pemahaman dan kesadaran masyarakat tentang Pemilu. Partisipasi kerap kali hanya dimaknai sebatas aktivitas menyalurkan hak suara (mencoblos), belum ke hal-hal yang lebih substantif seperti pengawalan untuk menghindari praktik curang dalam pemilu ( $\mathrm{TH}$, Wawancara 2019). Di samping itu, persoalan lama berkaitan dengan minimnya anggaran yang diakui oleh informan berdampak pada tidak efektifnya program sosialisasi oleh Bawaslu di tingkat daerah. Kesadaran politik masyarakat di tingkat bawah cenderung lebih berorientasi mengharap imbalan materi dibanding proaktif secara sukarela mengawal proses-proses Pemilu (FW, Wawancara 2019). Sejumlah persoalan diatas seolah tidak pernah menemui titik akhir dan selalu muncul di setiap penyelenggaraan pemilu.

\subsection{Kultur Patrimonial}

Di samping sejumlah persoalan kinerja Bawaslu, aspek sosio-kultural di Jawa Timur menarik untuk dilihat sebagai salah satu indikator yang memengaruhi rendahnya keterlibatan masyarakat di dalam seluruh proses Pemilu. Berdasarkan pendapat ahli, terdapat tiga perspektif sosio-kultural Jawa Timur yang paling dominan, yakni budaya Arek, Tapal Kuda (Pandalungan) dan Mataraman. Ketiga wilayah subkultur tersebut tentunya merepresentasikan karakteristik masyarakat yang berbeda. Merujuk pada penelitian Zuhro (2009) mengenai nilai-nilai budaya politik lokal menjelaskan, wilayah Arek yang meliputi Surabaya, Malang, Jombang, Mojokerto, Gresik dan sekitarnya, secara umum lekat dengan budaya arek-nya 
yang artikulatif dan ekspresif, sebuah karakteristik masyarakat yang terbuka, egaliter dan relatif mudah menerima nilai-nilai demokrasi. Di Provinsi ujung timur pulau Jawa itu juga dikenal dengan istilah bloko suto (sikap apa adanya), sebuah sikap yang menggambarkan keterbukaan, transparansi dan keberanian melakukan koreksi terhadap pihak lain tanpa harus dibayang-bayangi perasaan ewuh pakewuh dan melanggar tatakrama sopan santun.

Sementara itu, di wilayah Tapal Kuda seperti Probolinggo, Lumajang, Jember, Bondowoso, Situbondo lebih menunjukan budaya "mendalungan" ketimbang Arek. Penduduk di daerahdaerah tersebut sebagian adalah hasil perkawinan campuran antara suku Jawa dan Madura atau penduduk Madura yang tinggal di luar pulau Madura tapi masih berada di wilayah Jawa Timur. Meskipun tidak persis sama dengan budaya Arek, dalam beberapa hal menunjukan kemiripan dalam hal keterbukaan dan mengekspresikan keinginannya. Selain itu, yang menarik adalah masyarakat "mendalungan" juga cenderung bersifat komunal, patuh dan taat pada kyai atau tokohnya. Sedangkan di kawasan Mataraman, daerah yang secara geografis berdekatan dengan Jawa Tengah, seperti di Kediri, Blitar, Tulungagung, Trenggalek, Madiun dan kawasan sekitarnya mengalami semacam proses akulturasi dengan budaya Jawa Tengah-an yang cenderung feodal. Akan tetapi, identitas ke-Jawa Timuran tetap dominan sehingga nilai-nilai egalitarianisme yang menjadi salah satu pilar penting demokrasi mudah ditemukan di sebagian besar wilayah Jawa Timur.
Dalam Pemilu Serentak 2019, angka partisipasi di ketiga kawasan tersebut (Arek, Mataraman dan Pandalungan) secara umum memperlihatkan adanya peningkatan partisipasi memilih. Total presentase partisipasi memilih di Jawa Timur meningkat yaitu mencapai $82,35 \%$ (Amaluddin, 2019). Namun, secara bersamaan, di ketiga wilayah subkultur tersebut menunjukan perbedaan dalam aspek keterlibatan masyarakat dalam mengawal proses pemilu.

Tabel 1.2. Data Pelanggaran Pemilu Tahun 2019 Berdasarkan Subkultur Wilayah

\begin{tabular}{|c|c|c|}
\hline $\begin{array}{l}\text { Sub Kultur } \\
\text { Jawa Timur }\end{array}$ & $\begin{array}{c}\text { Jumlah } \\
\text { Temuan } \\
\text { Pelanggaran }\end{array}$ & $\begin{array}{c}\text { Jumlah } \\
\text { Laporan } \\
\text { Pelanggaran }\end{array}$ \\
\hline \multicolumn{3}{|l|}{ Arek } \\
\hline Kota Surabaya & 344 & 6 \\
\hline Kab. Gresik & 757 & 5 \\
\hline Kota Malang & 119 & 1 \\
\hline Kab. Malang & 1149 & 3 \\
\hline Kota Batu & 137 & 2 \\
\hline \multicolumn{3}{|l|}{ Mataraman } \\
\hline Kab. Magetan & 542 & 0 \\
\hline Kab. Madiun & 151 & 1 \\
\hline $\begin{array}{l}\text { Kab. } \\
\text { Bojonegoro }\end{array}$ & 237 & 0 \\
\hline Kab. Tuban & 315 & 0 \\
\hline Kab. Kediri & 641 & 0 \\
\hline \multicolumn{3}{|l|}{ Pandalungan } \\
\hline Kota Pasuruan & 159 & 0 \\
\hline $\begin{array}{l}\text { Kab. } \\
\text { Situbondo }\end{array}$ & 150 & 0 \\
\hline $\begin{array}{l}\text { Kab. } \\
\text { Pamekasan }\end{array}$ & 119 & 0 \\
\hline Kab. Sampang & 75 & 1 \\
\hline
\end{tabular}

Sumber: Bawaslu Jatim, 2019

Dari data ketiga kawasan subkultur di atas (Arek, Mataraman dan Pandalungan), menggambarkan perbedaan keterlibatan 
masyarakat dalam melaporkan dugaan pelanggaran pemilu. Data Bawaslu Jawa Timur (2019) tersebut menunjukan bahwa temuan laporan masyarakat mengenai dugaan pelanggaran pemilu didominasi oleh kabupaten/kota yang masuk dalam subkultur Arek. Hal ini berkorelasi dengan kajian Zuhro (2009) yang menjelaskan bahwa perilaku politik massa di daerah Arek lebih rasional dibandingkan daerah Mataraman dan Pendalungan yang realitas perilaku politiknya sering berbenturan dengan kultur yang patrimonial. Menurut Zuhro (2009), partisipasi politik di Jawa Timur cenderung banyak dipengaruhi oleh ketokohan atau kharismatik seorang tokoh.

\subsection{Masyarakat yang Terkooptasi}

Masalah - masalah partisipasi masyarakat Jawa Timur dalam pengawasan pemilu, sebagaimana paparan temuan di atas, tidak serta merta menitikberatkan pada persoalan prosedural semata. Ada persoalan-persoalan serius di dalam praktik politik yang terjadi di Jawa Timur sehingga berdampak pada independensi masyarakat di dalam mengawal proses pemilu di setiap tingkatan. Data menunjukkan ketimpangan perbandingan antara jumlah pelanggaran kontestan pemilu dengan laporan masyarakat, terjadi di seluruh wilayah kota/kabupaten di Jawa Timur. Artinya hampir di seluruh wilayah kota/kabupaten respon masyarakat terhadap tingginya praktik pelanggaran pemilu sangat rendah. Padahal angka partisipasi memilih masyarakat Jawa Timur sangat tinggi yaitu mencapai $82,35 \%$ tingkat kehadiran di bilik suara.

Fenomena partisipasi semacam ini menunjukkan adanya anomali. Tingginya partisipasi politik masyarakat dalam menentukan hak pilihnya tidak secara otomatis diikuti oleh keterlibatannya di dalam proses-proses mengawal suaranya. Sehingga meski tingkat partisipasi memilih sangat tinggi tidak menjamin penyelenggaraan pemilu berjalan secara fair.

\section{Gambar 2. Data Perbandingan Jumlah Temuan dan Laporan Pelanggaran Pemilu 2019 di Jawa Timur}

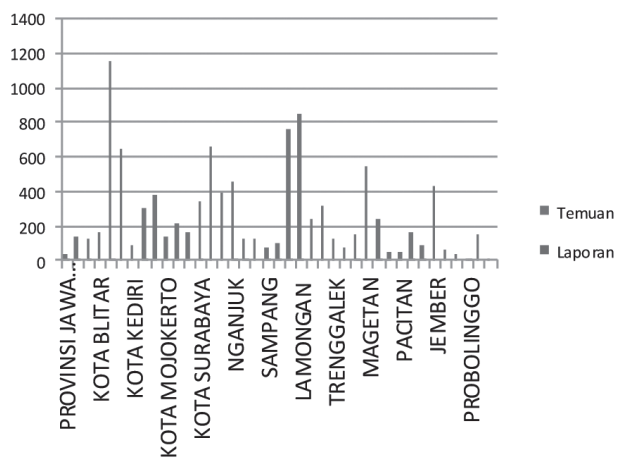

Sumber: Bawaslu Jawa Timur, 2019

Informan TH (2019) dalam hasil wawancara menjelaskan tingginya partisipasi memilih masyarakat salah satunya disebabkan oleh kondisi kultural masyarakat Jawa Timur yang komunal. Kondisi yang sedemikian memungkinkan masyarakat beramai-ramai bersama-sama turut hadir ke TPS.

"mereka akan aware ketika yang menjadi kontestan pemilu adalah orang dekatnya, baik itu teman, saudara, tetangga, satu organisasi, sehingga ikatan emosional itu terbentuk dan menggerakkan warga masyarakat yang komunal tersebut turut hadir memberikan hak suara. Bagaimana dengan yang tidak memiliki ikatan emosional tadi, biasanya salah satu intervensi yang menjadi alasan memilih karena politik uang (Wawancara TH, 31 Juli 2019). 
Salah satu yang menjadi temuan penting di dalam penelitian ini adalah maraknya praktik politik uang. Praktik politik semacam ini sudah mengakar dan tumbuh subur di setiap perhelatan demokrasi prosedural. Di Kota Probolinggo misalnya, hasil kuesioner yang dibagikan Bawaslu Kota Probolinggo sebagai upaya pencegahan pelanggaran Pemilu Serentak 2019 menunjukkan fakta bahwa masyarakat sekitar sangat permisif dengan praktik politik uang.

"Pada Pemilu Serentak 2019 lalu, kami menemukan uang di dalam tas milik istri seorang caleg yang disiapkan untuk dibagikan kepada masyarakat. Ketika ditanyakan kepada masyarakat, mereka mau saja menerima, dan sebenarnya mereka mengharap uang-uang semacam itu. Seperti hasil kuesioner yang dibagikan Bawaslu saat sebelum Pemilu, memang masyarakat disini sudah terbiasa dengan praktik politik uang yang terjadi sebelumnya-sebelumnya, dan itu alasan mengapa mereka mau datang ke TPS (Wawancara AF, 27 Juli 2019).

Praktik politik semacam ini terjadi hampir di tiap kota/kabupaten di Jawa Timur. Informan - informan penelitian membenarkan adanya praktik tersebut yang banyak terjadi di wilayah desadesa. Masyarakat biasanya menceritakan praktik politik uang kepada teman terdekat. Sekaligus mengkonfirmasi ketidakmungkinan masyarakat melaporkan dugaan praktik politik uang kepada Bawaslu saat proses Pemilu berlangsung meskipun hal itu terjadi di depan mata. Ini dikarenakan selain mereka terlibat sebagai penerima, mereka juga diuntungkan karena mendapatkan uang. Kondisi semacam ini berhubungan logis dengan pasifnya masyarakat di dalam proses pengawasan dan pelaporan.

Temuan penelitian berikutnya terjadi di wilayah Madura yaitu adanya manipulasi penghitungan hasil perolehan suara calon anggota DPR RI dapil Jawa Timur XI yang kasusnya saat ini tengah menunggu proses sidang sengketa di Mahkamah Konstitusi dan DKPP. Salah seorang informan menyebutkan dugaan adanya peran elit lokal dan penyelenggara pemilu setempat di dalam proses memanipulasi penghitungan hasil suara.

"C1 hasil rekap suara di TPS, kemudian naik ke kecamatan masih aman. Ketika sudah di tingkat kabupaten berubah suaranya. Local strong man ini mengkooptasi penyelenggara pemilu dengan mengkondisikan hasil rekapitulasi tingkat kabupaten. Saat penghitungan di TPS dan kecamatan terbuka, masyarakat bisa ikut lihat, tapi begitu rapat pleno tertutup di kabupaten suara sudah berubah (Wawancara R, 4 Agustus 2019)."

Berkaitan dengan kesaksian seseorang untuk melaporkan dugaan pelanggaran pemilu tersebut diakui informan $R$ (2019) ditemukan adanya intimidasi, terutama untuk bersaksi ke Sidang Mahkamah Konstitusi. Praktik intimidasi kepada masyarakat sehingga menimbulkan rasa takut dan keterancaman pada keselamatan seseorang memang terjadi. la menjelaskan praktik kompetisi politik tidak sehat di Madura pada Pemilu Serentak 2019 lalu terjadi dalam dua bentuk, yaitu atas (melalui manipulasi penghitungan suara) dan bawah (melalui praktik politik uang). 
Jelas kiranya bahwa fenomena diatas menunjukkan persoalan demokrasi yang sangat serius. Mengingat praktik politik uang dan intimidasi terhadap masyarakat pada akhirnya sangat berdampak pada keleluasaan masyarakat untuk aktif tergerak menciptakan suasana pemilu yang fair. Kedua temuan tersebut mengkonfirmasi hubungan sebabakibat secara logis perihal rendahnya tingkat laporan masyarakat terhadap dugaan pelanggaran kontestan pemilu, sementara temuan pelanggaran yang diperoleh Bawaslu di masing-masing kota/kabupaten sangat tinggi.

Jika fenomena di atas di sandingkan dengan pendekatan elit di dalam proses kompetisi, maka logis jika proses politik dianggap sebagai permainan elit. Para tokoh yang bertindak sebagai kontestan pemilu menjalankan peran dengan sumberdaya yang mereka miliki untuk mengamankan kepentingan pribadi mereka. Bagi Schumpeter demokrasi secara sederhana adalah suatu mekanisme pasar. Para pemilih adalah konsumen, para politisi adalah wiraswastanya (Schumpeter, 1952, hal. 269). Linier dengan mekanisme ini, kompetisi di dalam proses politik dimaknai sebagai kompetisi antar elit untuk memburu keutungan. Keuntungan dalam konteks kompetisi elektoral adalah meraih dukungan massa untuk memperoleh suara terbanyak. Elit akan mengusahakan apapun yang mereka yakini untuk meraih sebesar-besarnya dukungan (Downs, 1957, hal. 295-296).

\section{Simpulan}

Simpulan utama dari penelitian ini terdiri dari beberapa aspek pokok. Masalah-masalah implementasi pengawasan partisipatif di Jawa Timur secara substantif disebabkan karena beberapa faktor. Pertama, tidak adanya inovasi kinerja yang dilakukan oleh Bawaslu di tingkat daerah dalam mengimplementasikan pengawasan partisipatif sehingga sejumlah masalah klasik yang terjadi di setiap penyelenggaran pemilu masih seringkali ditemui. Misalnya alasan minimnya anggaran dalam pelibatan masyarakat yang berdampak pada tidak efektinya proses sosialisasi, serta rendahnya pemahaman masyarakat.

Kedua, karakter sosio-kultural masyarakat Jawa Timur yang patrimonial, dimana realitas perilaku politik massa yang sebagian besar berada di wilayah kabupaten sering berbenturan dengan kultur yang patrimonial. Partisipasi politik di Jawa Timur cenderung banyak dipengaruhi oleh ketokohan atau kharismatik seorang tokoh.

Ketiga, kondisi masyarakat yang terkooptasi. Selain akar persoalan yang berkaitan dengan pengetahuan masyarakat dan berdampak pada ketidaktahuan masyarakat mengenai aturan main di dalam proses politik, praktik politik uang menciptakan masyarakat yang permisif terhadap praktik-praktik pelanggaran pemilu dan pasif dalam penegakannya. Di samping itu juga ditemukannya intimidasi oleh kontestan pemilu kepada masyarakat pemilih sehingga menimbulkan rasa takut dan keterancaman keamanan diri. Keseluruhan persoalan diatas mengkooptasi masyarakat Jawa Timur baik secara psikologis maupun sosiologis, dan menjadikan tidak terlibatnya masyarakat di dalam partisipasi politik di seluruh tingkatan pemilu.

Andy IIman Hakim \& Deydeandy L. Iztighfar 


\section{DAFTAR PUSTAKA}

Amaluddin. (2019, Mei 13). Partisipasi Pemilih di Jatim Melampaui Capaian Nasional. Diakses dari https://m.medcom.id/pemilu/news-pemilu/zNAL57zK-partisipasipemilih-di-jatim-melampaui-capaian-nasional.

Bawaslu RI. (2018, Januari 14). Panduan Pusat Pengawasan Partisipatif. Diakses dari https://bawaslu.go.id/id/publikasi/panduan-pusat-pengawasan-partisipatif.

Bawaslu RI. (2019, Mei 2). Hasil Pengawasan Pemilu 2019. Diakses dari https://www. bawaslu.go.id/id/hasil-pengawasan/pemilu-2019.

Creswell, J. W. (2008). Educational Research. Planning, Conducting, and Evaluating Qualitative \& Quantitative Approach. London: Sage Publications.

Downs, Anthony. (1957). An Economic Theory of Democracy, Harper \& Row, Publishers.

Farisa, F. (2019, Mei 2007). KPU Sebut Partisipasi Pemilih pada Pemilu 2019 Mencapi 8

Persen diakses dari https://nasional.kompas.com/read/2019/05/27/16415251/ kpu-sebut-partisipasi-pemilih-pada-pemilu-2019-capai-81-persen.

Huntington, S. P. (1991). The Third Wafe: Democratization in The Late Twentieth Century. University of Oklahoma Press.

Huntington, S. P., \& Nelson, J. M. (2014). Partisipasi Politik di Negara Berkembang. Jakarta: Rineka Cipta.

Junaidi, Veri. (2013). Pelibatan dan Partisipasi Masyarakat dalam Pengawasan Pemilu. Jakarta: Perludem dan The Asia Foundation.

Mas'oed Mohtar.,\& MacAndrews, C. (2008). Perbandingan Sistem Politik. Yogyakarta: Gadjah Mada University.

Megantoro, Widi. (2014). Peran Bawaslu dan Dinamika Hubungan Kelembagaannya dalam Proses Pengawasan Pemilu Pasca Reformasi di Indonesia (Tesis). Depok, Fakultas Hukum, Universitas Indonesia.

Nurhasim, M. (2016, Oktober 4). Partisipasi Pemilih pada Pemilu 2014: Studi Penjajakan. Diakses dari http://lipi.go.id/publikasi/partisipasi-pemilih-pada-pemilu-2014studi-penjajakan/14478.

OSCE. (2010). Election Observation Handbook. Warsaw Poland: OSCE Office for Democratic Institutions and Human Rights (ODIHR).

Schumpeter, Joseph. (1952) Capitalism, Socialism, and Democracy, New York, Harper.

Surbakti, Ramlan.,\& Fitrianto, Hari. (2015). Transformasi Bawaslu dan Partisipasi Masyarakat dalam Pengawasan Pemilu. Jakarta: Kemitraan Partnership.

Varma, S.P. (1999). Teori Politik Modern. Jakarta: PT. Raja Grafindo Persada.

Weiner, Myron. (1971). Political Participation: Crises of the political process in Leonard Binder and others, Crises and Sequences in Political Development. Pricenton University Press.

Wawancara dengan AF pada tanggal 27 Juli 2019.

Wawancara dengan FW pada tanggal 2 Juli 2019.

Wawancara dengan R pada tanggal 4 Agustus 2019.

Wawancara dengan TH pada tanggal 31 Juli 2019.

Zuhro, R. Siti, dkk. (2009). Demokrasi Lokal: Perubahan dan Kesinambungan NilaiNilai Budaya Politik Lokal di Jawa Timur, Sumatera Barat, Sulawesi Selatan dan Bali. Yogyakarta: Ombak. 